\title{
HUBUNGAN UMUR DAN JUMLAH ANAK TERHADAP PENGGUNAAN METODE KONTRASEPSI DI PUSKESMAS BULAK BANTENG SURABAYA
}

\author{
Nur Dewiyanti \\ Promosi Kesehatan dan Ilmu Perilaku, Universitas Airlangga \\ Email: nurdewiyanti26@gmail.com
}

\begin{abstract}
Contraception is one of the tools that can be made by the community to help control the rate of population's growth. The users' rate of long-term contraceptive methods are still low compared to non-long-term contraceptive methods whose interest are still high. The purpose of this study was to analyzing the factors that influence the use of contraceptive methods in the work area of Bulak Banteng Health Center Surabaya. This study was observational analytic, with cross sectional design. Subjects were selected by simple random sampling. This study analyzed the influence of the factors of each independent variabels on the use of long-term contraceptive methods. The population in this study were all PUS (fertile age couples) women about 15-49 years old which their family were using long-term and non long-term contraceptive methods and resided on regional of Bulak Banteng Public Health Center Surabaya. The independent variabels used were age and number of children that respondens have. The dependent variabel was contraception using. Obtained a total of 94 respondents. Data collected was analyzed by univariate and bivariate. The bivariate test results showed that the age of the respondents did not have a relationship with the use of the method of conraception ( $p=0.074>\alpha=0.05)$ while the number of children had a significant relationship with the use of contraceptive methods $(p=0.048<\alpha=0.05)$.
\end{abstract}

Keywords: Contraception Method, Age, Number of Children

\begin{abstract}
ABSTRAK
Kontrasepsi merupakan salah satu alat yang dapat dilakukan masyarakat untuk membantu mengendalikan lajunya pertambahan penduduk. Jumlah pengguna metode kontrasepsi jangka panjang masih rendah dibandingkan non metode kontrasepsi jangka panjang yang peminatnya masih tinggi. Tujuan dari penelitian ini adalah menganalisis faktor yang berpengaruh terhadap penggunaan metode kontrasepsi di wilayah kerja Puskesmas Bulak Banteng Surabaya. Penelitian ini bersifat analitik observasional, dengan desain menurut waktumya bersifat cross sectional study. Subjek diambil dari populasi dengan cara simple random sampling. Penelitian ini menganalisis pengaruh faktor setiap variabel bebas terhadap penggunaan metode kontrasepsi jangka panjang. Populasi dalam penelitian ini adalah semua wanita PUS (Pasangan Usia Subur) berusia 15-49 tahun yang merupakan akseptor KB metode kontrasepsi jangka panjang dan non metode kontrasepsi jangka panjang yang bertempat tinggal di wilayah kerja Puskesmas Bulak Banteng Surabaya. Variabel bebas yang digunakan adalah usia dan jumlah anak yang dimiliki responden. Variabel terikat yang digunakan adalah penggunaan metode kontrasepsi. Didapatkan jumlah sebanyak 94 responden. Data yang telah
\end{abstract}


terkumpul dianalisis secara univariat dan bivariat. Hasil uji bivariat menunjukkan bahwa usia responden tidak memiliki hubungan dengan penggunaan metode konrasepsi $(p=0,074>\alpha=0,05)$ sedangkan pada jumlah anak memiliki hubungan yang signifikan dengan penggunaan metode kontrasepsi $(\mathrm{p}=0,048<\alpha=0,05)$.

Kata kunci: Metode Kontrasepsi, Usia, Jumlah Anak

\section{PENDAHULUAN}

Negara Indonesia adalah salah satu negara berkembang yang memiliki pertumbuhan penduduk cukup tinggi. Indonesia menempati urutan negara keempat, dengan jumlah penduduk sebanyak 264 juta jiwa, setalah negara Cina, India, dan Amerika Serikat. Di antara negara ASEAN, Indonesia dengan luas wilayah terbesar tetap menjadi negara dengan penduduk terbanyak pertama disusul dengan negara Filipina di urutan kedua dengan jumlah penduduk 105 juta jiwa. Negara yang memiliki angka TFR (Total Fertility Rate) atau angka kelahiran total tertinggi ditempati oleh Nigeria dengan TFR 7,3. Indonesia diantara negara ASEAN menempati urutan kelima dengan TFR yang tinggi setelah Timor Leste, Laos, Filipina, Kamboja. Angka kelahiran total atau TFR Indonesia mencapai 2,4, angka tersebut masih berada diatas rata-rata TFR pada negara ASEAN yaitu sebesar $2,3 .{ }^{1}$

Di Indonesia angka TFR yang tercatat pada SDKI mengalami fluktiatif dari tahun 1971 hingga 2003, dan terus meningkat hingga 2012. TFR pada Sensus Penduduk tahun 1971 sebesar 5,6 anak per wanita usia reproduksi, dan menurun hingga 2,8 anak per wanita pada SDKI
1997. Pada SDKI 2002-2003 TFR menurun menjadi 2,6 anak per wanita. Namun pada SDKI 2007 dan SDKI 2012 angka TFR tidak mengalami penurunan lagi yaitu tetap 2,6 anak per wanita. ${ }^{2,3}$

Program KB merupakan salah satu program yang menjadi fokus di bidang kesehatan dalam Rencana Pembangunan Jangka Menegah Nasional periode 2015-2019. Program KB juga merupakan salah satu prioritas dalam 9 agenda prioritas pembangunan (Nawacita) yaitu pada agenda prioritas nomor 5 yang isinya "Meningkatkan Kualitas Hidup Manusia Indonesia" melalui Pembangunan Kependudukan dan Keluarga Berencana yang akan diwujudkan oleh kabinet kerja. Hal tersebut diharapkan program KB mampu mengatasi permasalahan kependudukan di Indonesia sehingga tercipta SDM yang berkualitas. Laju pertumbuhan penduduk tahun 2010-2014 sekitar $1,40 \%$ per tahun. ${ }^{4}$

Berdasarkan UU No 52 Tahun 2009, keluarga berencana adalah suatu program masyarakat yang menghimpun dan mengajak segenap potensi masyarakat untuk berpartisipasi aktif dalam melembagakan dan membudayakan Norma Keluarga Kecil Bahagia dan Sejahtera 
dalam rangka meningkatkan mutu sumber daya manusia melalui pendewasaan usia perkawinan (PUP), pengaturan kelahiran, pembinaan ketahanan keluarga, peningkatan kesejahteraan keluarga kecil bahagia dan sejahtera.

Selain itu didalam UU No 52 tahun 2009, Bab 1 pasal 1 ayat (8) tentang Perkembangan dan Pembangunan Keluarga Sejahtera adalah Upaya mengatur kelahiran anak, jarak dan usia ideal melahirkan, mengatur kehamilan, melalui promosi perlindungan dan bantuan sesuai dengan hak reproduksi untuk mewujudkan keluarga yang berkualitas. Program keluarga berencana berperan penting sebagai pengelola, penggerak, pengendali memberdayakan serta memberikan pendekatan kepada masyarakat untuk meningkatkan pencapaian pengendalian program KB.

Sasaran pelaksanaan program KB yaitu Pasangan Usia Subur. Pasangan Usia Subur (PUS) adalah pasangan suami-istri yang terikat dalam perkawinan yang sah, yang istrinya berumur antara 15 sampai dengan 49 tahun. Peserta KB Aktif adalah Pasangan Usia Subur (PUS) yang saat ini menggunakan salah satu alat kontrasepsi tanpa diselingi kehamilan. Peserta KB Baru adalah pasangan usia subur yang baru pertama kali menggunakan alat/cara kontrasepsi dan atau pasangan usia subur yang kembali menggunakan metode kontrasepsi setelah melahirkan/keguguran. ${ }^{5}$

Mayoritas masyarakat Indonesia lebih memilih kontrasepsi non MKJP. Hal tersebut terlihat dari peserta KB baru yang cenderung lebih memilih suntikan dibandingkan alat kontrasepsi lain, sehingga metode kontrasepsi suntik mengalami peningkatan, sebaliknya pemakaian metode kontrasepsi jangka panjang (MKJP) cenderung menurun dari waktu ke waktu. Sementara itu, kebijakan program KB pemerintah saat ini lebih mengarah pada penggunaan kontrasepsi MKJP (IUD, Implant, MOW dan MOP). Anjuran tersebut didasarkan pada pertimbangan ekonomi penggunaan alat kontrasepsi non hormonal dan MKJP yang lebih efisien. $^{6}$

Kontrasepsi suntik dan pil merupakan kontrasepsi Non-MKJP yang paling diminati masyarakat. Angka putus pakai KB tertinggi yaitu pada pengguna kontrasepsi pil (40,7\%), sedangkan untuk kontrasepsi jenis suntik yaitu $(24,7 \%) .^{2}$ Pemakaian MKJP memiliki banyak keuntungan, baik dilihat dari segi program maupun dari sisi pengguna. Disamping mempercepat penurunan TFR, penggunaan kontrasepsi MKJP juga lebih efisien karena dapat dipakai dalam waktu yang lama serta lebih aman dan efektif. Dilihat angka kegagalan MKJP relatif lebih rendah dibanding NonMKJP. Angka kegagalan MKJP dilaporkan sebesar 0-2 per 1000 pengguna, sedangkan metode Non-MKJP dilaporkan terjadi lebih dari 10 per 1000 pengguna. $^{7}$

Jawa Timur merupakan salah satu provinsi di Indonesia yang memiliki jumlah penduduk terbanyak kedua setelah provinsi Jawa Barat. 
Berdasarkan Profil Kesehatan Provinsi Jawa Timur tahun 2016, jumlah penduduk provinsi Jawa Timur pada tahun 2016 sebanyak 39.075.152 juwa. Peserta KB aktif terbagi menjadi dua jenis alat kontrasepsi KB yaitu MKJP dan Non-MKJP. Menurut hasil pelayanan KB baru di Provinsi Jawa Timur tahun 2016, yang menggunakan MKJP meliputi IUD (5.8\%), implant (12.2\%), MOW (1.7\%) dan MOP $(0.1 \%)$. Pengguna Non-MKJP meliputi suntik $(60.3 \%)$, pil $(17.6 \%)$, kondom $(2.3 \%)$. Data tersebut menunjukkan bahwa penggunaan alat kontrasepsi di Jawa Timur masih didominasi oleh Non-MKJP dari pada MKJP. ${ }^{8}$

Surabaya merupakan Ibu Kota Provinsi Jawa Timur dengan jumlah penduduk sebesar 2.862.406 jiwa (Kajian Kependudukan tahun 2015). Menurut hasil Susenas 2015, kota Surabaya memiliki angka CPR sebesar 57,59\% dimana angka tersebut belum mencapai rata-rata CPR yang ada di Jawa Timur yakni sebesar 63,79\%.9 Pemakaian Metode Kontrasepsi Jangka Panjang (MKJP) terdiri dari IUD, Implant, MOW dan MOP di kota Surabaya pada tahun 2014-2016 mengalami fluktuatif. Tahun 2014 jumlah pemakai MKJP sebanyak 60.899 orang (16,86\%), tahun 2015 terjadi peningkatan pemakai MKJP sebanyak 63.500 orang $(16,19 \%)$, tahun 2016 terjadi penurunan pemakai MKJP sebanyak 60.593 orang $(16,56 \%)$. Pada pemakaian Non-Metode Kontrasepsi Jangka Panjang (Non-MKJP) terdiri dari suntik, pil dan kondom dari tahun 2014-
2016 juga mengalami fluktiatif. Tahun 2014 jumlah pemakai Non-MKJP sebanyak 300.276 orang $(83,14 \%)$, tahun 2015 terjadi peningkatan pemakai Non-MKJP sebanyak 328,624 orang $(83,61 \%)$, tahun 2016 terjadi penurunan pemakai Non-MKJP sebanyak 305.277 orang $(83,44 \%)$. Pemakaian MKJP maupun NonMKJP terjadi naik-turun atau fluktuatif setiap tahunnya tetapi minat untuk memakai NonMKJP lebih banyak dari pada pemakai MKJP. ${ }^{10,11,12}$

Dari 63 Puskesmas yang ada di Surabaya, Puskesmas yang memiliki jumlah peserta KB Aktif yang memilih MKJP terendah pada dari tahun 2014 hingga tahun 2016 adalah Puskesmas Bulak Banteng. Jumlah akseptor KB MKJP di Puskesmas Bulak Banteng pada tahun 2014 hanya memiliki persentase $2,78 \%$ atau sebanyak 130 orang dari 60.899 pengguna di seluruh puskesmas di Surabaya, pada tahun 2015 memiliki persentase $1,39 \%$ atau sebanyak 65 orang dari 63.500 pengguna di seluruh puskesmas di Surabaya, pada tahun 2016 memiliki persentase $0,41 \%$ atau sebanyak 15 orang dari 60.593 pengguna di seluruh puskesmas di Surabaya. Dari tahun 2014 hingga tahun 2016, persentase angka yang diperoleh Puskesmas Bulak Banteng menempati posisi terendah dibandingkan dengan puskesmas lain dan setiap tahunnya mengalami penurunan. ${ }^{12}$

Sebuah penelitian menyatakan PUS yang berumur < 30 tahun cenderung memilih menggunakan non-MKJP, sedangkan PUS 
berumur $>30$ tahun lebih memilih mengunakan MKJP. PUS yang bekerja memiliki risiko lebih besar untuk memilih non-MKJP dibandingkan PUS yang tidak bekerja. Paritas (jumlah anak) memengaruhi pemilihan metode kontrasepsi, PUS yang memiliki anak kurang dari tiga memiliki risiko lebih untuk memilih non-MKJP dibandingkan PUS yang sudah memiliki tiga anak atau lebih. ${ }^{13}$

Berdasarkan hal tersebut, penulis ingin meneliti tentang "hubungan antara umur dan jumlah anak dengan penggunaan metode kontrasepsi jangka panjang.

\section{METODE PENELITIAN}

Penelitian ini menggunakan jenis penelitian yang bersifat analitik observasional dan menggunakan rancang bangun cross sectional dengan pendekatan kuantitatif. Populasi dalam penelitian ini adalah semua wanita PUS (Pasangan Usia Subur) berusia 1549 tahun yang merupakan akseptor KB yang bertempat tinggal di wilayah kerja Puskesmas Bulak Banteng. Perhitungan jumlah sampel dengan rumus Lemeshow ditemukan sebesar 94 responden. Responden diambil secara acak atau simpel random sampling.

Variabel bebas dalam penelitian ini adalah umur responden, jumlah anak yang telah dimiliki responden. Variabel terikat pada penelitian ini adalah penggunaan MKJP (Metode Kontrasepsi Jangka Panjang) yang berupa IUD, implant, MOW.
Data dikumpulkan dengan instrumen penelitian berupa kuesioner. Data primer dikumpulkan dengan menggunakan kuesioner yang ditanyakan langsung kepada responden. Data sekunder yaitu data yang diambil dari Dinas Kesehatan Kota Surabaya berdasarkan dokumen yang ada di Dinas Kesehatan Kota Surabaya terkait dengan penggunaan metode kontrasepsi.

Data yang telah terkumpul dianalisis secara univariat dan bivariat. Analisis univariat dilakukan untuk mendeskripsikan masingmasing variabel secara tunggal dalam bentuk persentase dan tabel distribusi frekuensi yang berisi tentang umur, penghasilan tiap bulan, jumlah anak dan penggunaan metode kontrasepsi. Setelah itu akan dilakukan uji bivariat dengan menggunaka chi-square yang bertujuan untuk melihat apakah ada hubungan antar variabel. Bila hasil nilai dari uji tersebut menunjukkan signifikan $(>0,05)$ maka ada hubungan antar variabel.

\section{HASIL DAN PEMBAHASAN}

\section{Analisis Univariat}

Tabel 1. Distibusi Umur Responden di Wilayah Kerja Puskesmas Bulak Banteng Surabaya 2018

\begin{tabular}{lrr}
\hline Umur & \multicolumn{2}{c}{ Jumlah $(\mathrm{n}=94)$} \\
\cline { 2 - 3 } & $\begin{array}{c}\text { Frekuensi } \\
(\mathrm{n})\end{array}$ & $\begin{array}{c}\text { Persentase } \\
(\%)\end{array}$ \\
\hline$<20$ tahun & 0 & 0,0 \\
$20-35$ tahun & 59 & 62,8 \\
$>35$ tahun & 35 & 37,2 \\
\hline Total & 94 & 100,0 \\
\hline
\end{tabular}


Berdasarkan Tabel 1 dapat dilihat bahwa sebagian besar responden berumur 20-35 tahun yaitu sebanyak 59 orang $(62,8 \%)$ sedangkan pada dibawah umur 20 tahun tidak ditemukan pada penelitian ini. Pembagian umur ini berdasarkan umur reproduksi yaitu reproduksi tidak sehat pada umur kurang dari 20 tahun dan lebih dari 35 tahun sedangkan reproduksi sehat yaitu pada umur 20 sampai 35 tahun.

Tabel 2. Distribusi Frekuensi Jumlah Anak Responden di Wilayah Kerja Puskesmas Bulak Banteng Surabaya 2018

\begin{tabular}{lrr}
\hline Jumlah Anak & \multicolumn{2}{c}{ Jumlah $(\mathrm{n}=94)$} \\
\cline { 2 - 3 } & $\begin{array}{c}\text { Frekuensi } \\
(\mathrm{n})\end{array}$ & $\begin{array}{c}\text { Persentase } \\
(\%)\end{array}$ \\
\hline 1-2 orang & 53 & 56,4 \\
\hline 3-4 orang & 38 & 40,4 \\
\hline > 4 orang & 3 & 3,2 \\
\hline Total & 94 & 100,0 \\
\hline
\end{tabular}

Jumlah anak yang dimiliki responden sebagian besar adalah memiliki anak 1-2 orang yaitu sebanyak 55 orang (58,5\%). Jumlah anak yang dimiliki responden merupakan banyaknya anak kandung yang dilahirkan oleh responden dan masih hidup saat penelitian ini berlangsung. Tabel 3. Distribusi Frekuensi Penggunaan Metode Kontrasepsi Responden di wilayah kerja Puskesmas Bulak Banteng Surabaya 2018

\begin{tabular}{lcc}
\hline Metode Kontrasepsi & \multicolumn{3}{c}{ Jumlah (n=94) } \\
\cline { 2 - 4 } & $\begin{array}{c}\text { Frekuensi } \\
\text { (n) }\end{array}$ & $\begin{array}{c}\text { Persentase } \\
\%\end{array}$ \\
\hline $\begin{array}{l}\text { MKJP (implant, } \\
\text { IUD, MOW) }\end{array}$ & 18 & 19,1 \\
\hline $\begin{array}{l}\text { Non MKJP (Pil, } \\
\text { Suntik) }\end{array}$ & 76 & 80,9 \\
\hline \multicolumn{1}{l}{ Total } & & 100,0 \\
\hline \multicolumn{1}{c}{ Berdasarkan Tabel 3 } & 94 & 100 dilihat bahwa
\end{tabular}
responden sebagian besar menggunakan metode kontrasepsi Non MKJP sebanyak 76 orang (80,9\%), sedangkan penggunaan MKJP sebesar 18 orang $(19,1 \%)$. Penggunaan non MKJP didominasi oleh akseptor $\mathrm{KB}$ suntik yaitu sebanyak 50 orang.

\section{Analisis Bivariat}

Tabel 4. Hubungan Antara Umur Responden dengan Penggunaan Metode Kontrasepsi Responden di Wilayah Kerja Puskesmas Bulak Banteng Surabaya 2018

\begin{tabular}{|c|c|c|c|c|c|c|}
\hline \multirow[t]{3}{*}{ Umur Responden } & \multicolumn{4}{|c|}{ Metode Kontrasepsi } & \multicolumn{2}{|c|}{ Jumlah } \\
\hline & \multicolumn{2}{|c|}{ Non MKJP } & \multicolumn{2}{|c|}{ MKJP } & \multirow[b]{2}{*}{$\mathrm{n}$} & \multirow[b]{2}{*}{$\%$} \\
\hline & $\mathrm{n}$ & $\%$ & $\mathrm{n}$ & $\%$ & & \\
\hline 20-35 Tahun & 51 & 86,4 & 8 & 13,6 & 59 & 100,0 \\
\hline$>35$ Tahun & 25 & 71,4 & 10 & 28,6 & 35 & 100,0 \\
\hline \multicolumn{7}{|c|}{ Signifikan $=0,074$} \\
\hline
\end{tabular}

Pada Tabel 4 dapat dilihat responden dengan umur antara 20-35 tahun menggunakan MKJP sebanyak 8 orang $(13,6 \%)$ dan responden dengan umur >35 tahun menggunakan MKJP sebanyak 10 orang $(28,6 \%)$. Dari hasil tersebut dapat dilihat terjadi peningkatan persentase pada responden dengan umur 20-35 tahun dan $>35$ tahun, sehingga dapat disimpulkan semakin tua 
umur responden semakin menggunakan MKJP. Dari hasil analisis statistik dengan menggunakan uji chi-square antara usia responden dengan penggunaan metode kontrasepsi dengan nilai $\mathrm{p}=$ 0,074. Karena nilai $\mathrm{p}$ tersebut lebih besar dari taraf nyata 0,05 atau $(0,074>0,005)$, hal ini menunjukkan bahwa tidak terdapat hubungan antara usia responden dengan penggunaan metode kontrasepsi.

Sebagian besar responden berumur 20-35 tahun yaitu sebesar $62,8 \%$. Responden tergolong usia reproduksi sehat, oleh karena itu perlu diperhatikan untuk menjaga dan memanfaatkan reproduksinya dengan metode keluarga berencana sehingga jumlah dan interval kehamilan dapat diperhitungkan untuk meningkatkan kualitas reproduksi dan kualitas generasi selanjutnya. Namun hasil penelitian ini menunjukkan bahwa umur responden di lokasi penelitian tidak mempunyai hubungan dengan pemilihan penggunaan metode kontrasepsi. Hal tersebut tidak sejalan dengan penelitian yang dilakukan Dewi (2017) yang menunjukkan adanya hubungan yang signifikan antara usia ibu dengan pemilihan metode kontrasepsi jangka panjang. ${ }^{14}$

Tabel 5. Hubungan Antara Jumlah Anak Responden dengan Penggunaan Metode Kontrasepsi Responden di wilayah kerja Puskesmas Bulak Banteng Surabaya 2018

\begin{tabular}{|c|c|c|c|c|c|c|}
\hline \multirow[t]{3}{*}{ Jumlah Anak Responden } & \multicolumn{4}{|c|}{ Metode Kontrasepsi } & \multirow{2}{*}{\multicolumn{2}{|c|}{ Jumlah }} \\
\hline & \multicolumn{2}{|c|}{ Non MKJP } & \multicolumn{2}{|c|}{ MKJP } & & \\
\hline & $\mathrm{n}$ & $\%$ & $\mathrm{n}$ & $\%$ & $\mathrm{n}$ & $\%$ \\
\hline $1-2$ orang & 46 & 86,8 & 7 & 13,2 & 53 & 100,0 \\
\hline 3-4 orang & 29 & 76,3 & 9 & 23,7 & 38 & 100,0 \\
\hline$>4$ orang & 1 & 33,3 & 2 & 66,7 & 3 & 100,0 \\
\hline \multicolumn{7}{|c|}{ Signifikansi $=0,048$} \\
\hline
\end{tabular}

Responden dengan jumlah anak 1-2 orang menggunakan MKJP sebanyak 7 orang (13,2\%), responden dengan jumlah anak 3-4 orang menggunakan MKJP sebanyak 9 orang $(23,7 \%)$, dan responden dengan jumlah anak $>4$ orang menggunakan MKJP sebanyak 2 orang $(66,7 \%)$. Dari hasil tersebut dapat dilihat terjadi peningkatan persentase responden dengan jumlah anak 1-2 orang, 3-4 orang dan > 4 orang, sehingga dapat disimpulkan semakin banyak jumlah anak yang dimiliki oleh responden, maka semakin tinggi pula penggunaan Metode Kontrasepsi Jangka Panjang (MKJP).

Seseorang yang berparitas lebih dari satu sudah seharusnya menjadi akseptor KB untuk mengatur atau menjarangkan kehamilannya, tetapi dewasa ini banyak akseptor $\mathrm{KB}$ yang masih mengalami kesulitan dalam menentukan pilihannya. ${ }^{15}$ Jumlah anak hidup mempengaruhi pasangan usia subur dalam menentukan metode kontrasepsi yang akan digunakan. Pada pasangan dengan jumlah anak masih sedikit terdapat 
kecenderungan untuk menggunakan metode kontrasepsi dengan efektivitas rendah, sedangkan pada pasangan dengan jumlah anak hidup banyak terdapat kecendurungan menggunakan kontrasepsi dengan efektivitas yang lebih tinggi. Berdasarkan hasil penelitian, responden yang memiliki anak 1-2 orang lebih banyak menggunakan Non MKJP. Hasil penelitian ini menunjukkan bahwa jumlah anak responden di lokasi penelitian ini mempunyai hubungan dalam pemilihan penggunaan metode kontrasepsi. Hal tersebut tidak sesuai dengan penelitian Dewi (2017) yang menunjukkan bahwa tidak ada hubungan antara jumlah anak dengan pemilihan metode kontrasepsi jangka panjang. ${ }^{14}$

\section{SIMPULAN DAN SARAN}

\section{Simpulan}

Hasil penelitian dapat disimpulkan bahwa tidak ada hubungan yang bermakna antara umur responden dengan penggunaan metode kontrasepsi dimana nilai $\mathrm{p}$ value lebih besar dari pada nilai $\alpha$ yaitu $0,074>0,05$. Akan tetapi, ada hubungan yang bermakna antara jumlah anak yang dimiliki responden dengan penggunaan metode kontrasepsi dimana nilai $\mathrm{p}$ value lebih kecil dari nilai $\alpha$ yaitu $0,048<0,05$.

\section{Saran}

Seseorang yang berparitas lebih dari satu anak sudah seharusnya menjadi akseptor $\mathrm{KB}$ untuk dapat mengatur atau menjarangkan kehamilannya.

\section{REFERENSI}

1. Population Reference Bureau. World Population Data Sheet 2017. 2017. http://www.prb.org/Publications/Datasheets /2017/2017-worldpopulation-datasheet.aspx

2. SDKI. Laporan Pendahuluan Survei dan Kesehatan Indonesia. Jakarta: Kementrian Kesehatan. 2012.

3. BKKBN. Pemantauan Pasangan Usia Subur Melalu Mini Survei 2013. Jakarta: BKKBN. 2014.

4. Badan Pusat Statistik. Survei Demografi dan Kesehatan Indonesia. Jakarta:BPS. 2014

5. Kementrian Kesehatan RI. Situasi dan Analisis Keluarga Berencana. Jakarta: Pusat Data dan Informasi. 2016

6. BKKBN. Analisis Hasil Mini Survei Tahun 2009-2011 Provinsi Jawa Timur. Surabaya: BKKBN. 2013.

7. Prawirohardjo, S. Keluarga Berencana Dalam Ilmu Kebidanan. Jakarta: Yayasan Bina Pustaka. 2009.

8. Dinas Kesehatan Provinsi Jawa Timur. Profil Kesehatan Jawa Timur 2016. Surabaya: Dinkes Provinsi Jawa Timur. 2016

9. Badan Pusat Statistik. Survei Sosial Ekonomi Nasional (Susenas) Tahun 2010: Jakarta: Badan Penelitian dan Pengembangan Kesehatan. 2015.

10. Dinkes Kota Surabaya. Profil Kesehatan Kota Surabaya 2014. Surabaya: Dinkes. 2014.

11. Dinkes Kota Surabaya. Profil Kesehatan Kota Surabaya 2015. Surabaya: Dinkes. 2015.

12. Dinkes Kota Surabaya. Profil Kesehatan Kota Surabaya 2016. Surabaya: Dinkes. 2016.

13. Fitrianingsih, A.D.R. Faktor Sosiodemografi yang Mempengaruhi Pemilihan Metode 
Kontrasepsi. Jurnal Kependudukan dan Biometrika. Universitas Airlangga. 2016.

14. Dewi. Hubungan Usia dan Paritas dengan Penggunaan MKJP pada Akseptor Baru di Puskesmas Lendah 1 Kulon Progo Yogyakarta. KTI. FIK Universitas 'Aisyiyah Yogyakarta. 2017.

15. Wiknjosastro, H. Ilmu Kebidanan. Jakarta: Yayasan Bina Pustaka. 2015

16. Arikunto, S. Manajemen Penelitian. Jakarta: Rineka Cipta. 2011.

17. BKKBN. Pelayanan Keluarga Berencana. Jakarta: BKKBN. 2011.

18. BKKBN. RPJNMN. Jakarta: BKKBN. 2015.

19. Irianto, K. Keluarga Berencana Untuk Paramedis \& Non Medis. Bandung: Yrama Widya. 2012.

20. Lemeshow, S. \& Lwaga, S.K. Besar Sampel Dalam. 1997.

21. Undang-Undang RI No. 52 tahun 2009 tentang perkembangan kependudukan dan pengembangan keluarga. Pasal 56, ayat 1,2: page 34. Republik Indonesia. 2009.

22. Saifuddin, A.B. Buku Panduan Pelayanan Kontrasepsi. Jakarta: EGC. 2010.

23. SDKI. Laporan Pendahuluan Survei dan Kesehatan Indonesia. Jakarta: Kementrian Kesehatan. 2007. 